\title{
The Influence of Model of Civic Education Practicum Based on Integrated Learning to Strengthening Student Character
}

\author{
Rahmat Rahmat \\ Universitas Pendidikan Indonesia \\ Bandung, Indonesia \\ rahmat003@upi.edu
}

\begin{abstract}
Activity of learning implementation is the core of education which is of course very important to be studied and developed. In line with the growth of progressive education that emphasizes that the importance of education as a means of "progress" or the liberation of learners demand changes in the learning system. One of the innovations developed in improving the learning process of Civics by using integrated learning through practicum. Innovation with the base of integrated learning applied to the course practicum held by each course as an integrated learning process in the field in an integrated manner. The purpose of this research is the impact of application of Civics practice based on integrated learning towards the development of student character. Research method: This research uses qualitative and quantitative approach (mixed method) with Research and Development design. Data collection techniques used observation, documentation, Focus Group Discussion, and questionnaires. Qualitative data analysis uses data collection steps, data reduction, data presentation, and inferences, and quantitative data analysis using correlation and regression. The subject of this research is students of Department of Civic Education, Universitas Pendidikan Indonesia. Result of research: 1) Implementation of model of Civics Practicum based on integrated learning covering initial activity, core activity, and final activity to reflect activity; 2) The impact of application of experimental model based on integrated learning on student character development has a significant effect of $52.3 \%$.
\end{abstract}

Keywords-character; integrated learning; model of Civics practicum; student

\section{INTRODUCTION}

Nowadays, along with the times and the progress of science and technology that very rapidly result in changes in all areas of life. These changes certainly have an impact on the central point of human resources education. Educational institutions are required to be able to organize the educational process optimally in order to improve the quality and quality of education in the midst of global competition. Improving the quality and quality of good education is expected to give birth to graduates who have high competitiveness to face the challenges and competition in the world of work [1]. Therefore, continuous and continuous reconstruction and revitalization of education is needed to achieve the quality and quality of education in line with expectations.
Activity of learning implementation is the core of education which is of course very important to be studied and developed. If there is no change in the learning process, then learners interpret the lesson just as the process of memory, the level of thinking was only at the stage of remembering, or cognitive achievements alone, has not achieved affective learning and value learning. The result resulted in the students easily carried away the flow of freedom and and individualism that had a direct impact on the moral quality of the nation. This is characterized by the occurrence of moral crisis that hit the young generation today [2].

In line with the growth of progressive education that emphasizes that the importance of education as a means of "progress" or the liberation of learners demand changes in the learning system. Progress in this progressive flow study means that education by the flow goes from the traditional school of education which always emphasizes the authority of educators and the authority of the text by offering excessive new perspectives, ways, and methods in the learning system.

Based on this view, Civics developed one of the innovations developed in improving the learning process of Civics by using integrated learning (integrated learning). According to Cohen and Manion there are three possible variations of integrated learning in relation to progressive education: integrated curriculum, integrated day, and integrated learning [3]. An integrated curriculum is an activity to organize the integration of various subject matter through a cross-cutting theme forming a meaningful whole so that the boundaries between the various fields of study are not strict or virtually non-existent. An integrated day of designing student activities from a classroom on a particular day to learn or do various activities according to their interests. Meanwhile, integrated learning refers to organized learning activities in a more structured manner that is based on certain themes or certain lessons as center centers / center of interest.

Innovation with the base of integrated learning applied to the course practicum held by each course as a process of learning directly in the field. Practice is a part of teaching that aims to get students to test and perform in real life, what is derived from theory and practice lesson [4]. The Citizenship Education Practicum, although not always using the laboratory, 
this field of science is also concerned with field practice. Basically practice is needed to apply the theories that the students get during the course material. Practicum in the social field is certainly different from practicum in science, because practice in social science is very closely related to social problems. This is in accordance with what is the basic competence of Citizenship Education [5], namely the first civic knowledge, civic skill, and civic disposition. Where the three competencies are not only obtained when learning in the classroom, but also outside the class (community) through practicum. So in general, learning Civics become an alternative in developing the character of learners.

Based on the above background, it is necessary to conduct research based on Research and Development in simple scale to produce model of Civic Education practice based on integrated learning in developing student character. This model of Civic Education Practicum based on integrated learning conceptually will be developed in the course practicum within the Department of Education of Civic Education, Universitas Pendidikan Indonesia. In particular, the problem is spelled out in the following questions: 1) How is the implementation of the model of Civics practice based on integrated learning in developing the character of the students? and 2) How is the effect of applying the Civics practice based on integrated learning model to the development of student character?

\section{Methodology}

This research is done by using "Research and Development" approach. Sugiyono argues that, research and development ( $R$ \& D) method is a research method used to produce a certain product, and test the effectiveness of the product [6]. Borg and Gall states that to test products that are still hypothetical used experiments. Once the product is tested, it can be applied [7]. The research procedure using Research and Development from Borg and Gall which has been adapted and held modifications in its stages into four, namely: 1) preliminary study; 2) Preparation of Conceptual Model; and 3) Validation and revision of the Conceptual Model; and 4) Implementation Model [7].

Subjects in this study were students of the Department of Civic Education, Universitas Pendidikan Indonesia who are following the subjects of Islamic Law, Customary Law, and Constitutional Law in the academic year 2017/2018 as many as 144 students. In this study, data collection instruments used include: 1) interviews, 2) observations, 3) documentation studies and 4) Questionnaire. Researchers use the analysis system during data collection and data analysis after data collection, Correcting the information, while data analysis after data collection, researchers are much involved in the presentation or display activities of data collected and analyzed before. Display is a format that provides systematic information to the reader about the current research [8]. For quantitative data, researchers used percentage and correlationregression data to see the impact of the integrated learning practice model.

\section{RESULT AND DISCUSSION}

\section{A. Results}

1) The Implementation of Civc Education Practicum Model Based on Integrated Learning: Civic Education practicum based on Integrated learning implemented in Bandung City Council included 45 students consisting of group representatives. Each class has a group representation of 15 people so that if combined with other subjects then amounted to 45 people. The subject of Integrity Civic Education Practicum based on integrated learning is consist a specific theme. An interesting theme was previously agreed to be a group study. The theme selection is determined by three classes on the subject of Customary Law, Constitutional Law and Islamic Law. The main study in this theme is related to the study of tolerance / peace. Tolerance / peace is seen from the perspective of Customary Law, Constitutional Law, and Islamic Law. The purpose of the practicum is intended so that students can directly observe the functions and authority of state institutions in Bandung City Council. The theme of tolerance study is formulated in addition to legal point of view, then studied in five areas, namely education, religion, law, government, and socio-culture.

Implementation of the Integrated Learning Civic Practicum Model includes a series of initial activities, core activities and end activities can be described as follows.

\section{a) Initial activity}

- Students are invited to discuss the appropriate interview instruments with the theme.

- Students inquire the library of related themes.

- Each group discusses in accordance with the field being studied and selected.

- Designing an interview instrument

- Coordinate with other team teams

\section{b) Core activities}

- Representative groups that participate in the practicum seek Bandung City Council commissions that match the group review

- The team interviewed members of the Bandung City Council in accordance with the instruments that have been formulated

- Other interview teams record and record the course of the conversation directly

- Questions and answers that have been recorded are packed into interview reports.

\section{c) Last activities}

- Representative group who served as an informant back to his group to share information that has been obtained 
- Other groups in charge of preparing reports begin to formulate reports of practicum in accordance with the systematic

- The lecturer concerned reflects on the activities of the integrated learning practice

2) The Influence of Civic Education Practicum Model Based on Integrated Learning To Strengthening Student Character: Based on the results of correlation test between implementation variables of integrated learning practice model (X) with its impact on the development of student character (Y), then obtained picture as follows.

TABLE I. CORRELATION OF VARIABEL X TO VARIABEL Y

\begin{tabular}{|c|c|c|c|}
\hline & & $\begin{array}{c}\text { Model } \\
\text { (Post Test) }\end{array}$ & $\begin{array}{c}\text { Student } \\
\text { Character } \\
\text { (Post Test) }\end{array}$ \\
\hline \multirow{3}{*}{ Model } & Pearson Correlation & 1 & $723^{* *}$ \\
\hline & Sig. (2-tailed) & &, 000 \\
\hline & $N$ & 21 & 21 \\
\hline \multirow{3}{*}{$\begin{array}{c}\text { Student } \\
\text { Character }\end{array}$} & Pearson Correlation & $723^{* *}$ & 1 \\
\hline & Sig. (2-tailed) &, 000 & \\
\hline & $N$ & 21 & 21 \\
\hline
\end{tabular}

Based on correlation table I above, then seen by using Pearson Product Moment correlation formula $\mathrm{r}=0,723$ and $\mathrm{P}$ value $($ Sig. $)=0,000$. Since P-Value $(\mathrm{Sig})=$,0.014 is smaller than $\alpha=0.05$, it can be stated that there is a significant linear relationship of 0.723 between the application of Civic practice model based on integrated learning with the development of student character. If interpreted by using Sugiyono rules [9], then the closeness of the relationship including the strong category between (0.60 - 0.799).

Based on regression test results, the results obtained as described in the table II as follows.

TABLE II. REGRESSION OF VARIABEL X TO Y

\begin{tabular}{|c|c|c|c|c|}
\hline Model & $\mathbf{R}$ & R Square & $\begin{array}{l}\text { Adjusted R } \\
\text { Square }\end{array}$ & $\begin{array}{l}\text { Std. Error of the } \\
\text { Estimate }\end{array}$ \\
\hline 1 &, $723^{a}$ &, 523 & ,498 & 5,26977 \\
\hline
\end{tabular}

Based on the results of regression calculations using SPSS 20 , it can be known the amount of coefficient determination variable $\mathrm{X}$ to variable $\mathrm{Y}$ is 523 or $52.3 \%$. That is, the variable $\mathrm{Y}$ influenced by the variable $\mathrm{X}$ of $52.3 \%$, while the remaining $47.7 \%$ influenced by other factors. Empirically the results of this study informs that the application of practicum based on integrated learning Civics have a positive and significant impact on the development of student character

\section{B. Discussion}

Based on the research findings that show the existence of positive and significant influence between the implementation of the model of Civics practice based on integrated learning in the lecture of Constitutional Law, Islamic Law and Customary
Law towards the development of student character, the results of this study provide some information below.

First, the material factors of the Civic Education Practicum based on integrated learning determine the process of forming students' understanding in applying the theories that are often studied in the classroom. The material is integratively packed based on a particular theme. An interesting theme was previously agreed to be a group study. The theme selection is determined by three classes on the subject of Customary Law, Constitutional Law and Islamic Law. The main study in this theme is related to the study of tolerance / peace. Tolerance / peace is seen from the perspective of Customary Law, Constitutional Law, and Islamic Law. Then the material is studied in five areas, namely education, religion, law, government, and social culture.

This lab model attempts to integrate several subjects or subject areas or materials in a single study [10]. Further Hernawan, et al. states, revealing this model is an integrated learning model oriented to the practice of learning in accordance with the needs of child development " [11]. This concept has long been proposed by John Dewey in order to integrate the development and growth of learners with the ability of knowledge [12]. Based on the concept, it is argued that integrated learning is an approach to develop the ability of reasoning in the formation of knowledge based on interaction with the environment and experience in life.

Integrated learning is closely related to the constructivism approach, Slavin in Trianto suggests that constructivism is an opinion that cognitive development is a process whereby children actively build systems of meaning and understanding of reality through their experiences and interactions [13]. In the constructivist view, children actively build knowledge by continually assimilating and accommodating new information; in other words, constructivism is a cognitive developmental theory that emphasizes the students' active role in building their understanding of reality.

Second, the implementation of the Integrated Learning Practicum Model in the Lectures consists of several indicators, among which are: 1) The suitability of the model with the learning component; and 2) Conformity of model with aktivitas value of student character. The result of data processing shows that the application of the integrated learning practice model in the lecture belongs to the 'Good' category and apply the principles of value learning to develop the character of the students. It is undoubtedly that through first-hand experiences, students can learn more easily than learning through secondary sources. In line with Bruner's suggestion that children learn by inactive patterns through learning (doing by doing) will be able to transfer the science they possess in various situations [14]. All activities in the integrated learning practice model involve hands-on experience for students as well as provide various understanding of the surrounding environment. Activities that do allow students to integrate knowledge and skills from one experience to another experience. In addition, integrating all areas of development, integrated learning also gives them the opportunity to develop their full potential optimally, such as practicing research skills, observing, classifying, exploring 
ideas, critical thinking, high-level thinking, democratic and responsible.

Third, the development of student character that is generated after the students apply the model of Civic Education practicum based on integrated learning looks the most prominent among other characters is the attitude of mutual cooperation. Each has an average of the following: 1) religious attitudes of $62.7 \%$; 2) a nationalist attitude of $60.2 \%$; 3) independent attitude of $73.1 \%$; 4) gotong royong attitude of $83.7 \%$, and 5 ) attitude of integrity of $55.6 \%$. In this case, the value of the gotong royong character reflects the act of appreciating the spirit of cooperation and shoulder to shoulder to solve common problems, establish communication and friendship, provide assistance / help to people in need. The subvalues of mutual cooperation include appreciation, cooperation, inclusiveness, commitment to joint decisions, consensus deliberations, help, solidarity, empathy, anti-discrimination, nonviolence and volunteerism [15]. The character here is the determining factor of a person in advancing his people. Relating to the importance of character factors, Lickona asserted that "The core problem facing our school is a moral one. All the other problems derive from it. Even academic reform depends on putting character first ". The core problem of the outer layer of our school is a moral. All other problems come from that. Even in the academic rearranging rely on the first foundation of character [16].

Fourth, empirically the results of this study informs that the application of Civics practice based on integrated learning has a positive and significant impact on the development of student character. Known magnitude coefficient of determination of variable $X$ to variable $Y$ is equal to 523 or $52,3 \%$. That is, the variable $\mathrm{Y}$ influenced by the variable $\mathrm{X}$ of $52.3 \%$, while the remaining $47.7 \%$ influenced by other factors. With the increasing character of students affected by the above variables, then each student must get character education through integration in each subject influenced by the learning model

In this case, the character must be developed in the individual (student), especially if the student does not get character education at home [17], so that the campus has a very important role in character education of children, "Character Education" side, namely: "first, the character is a congenital condition and the human can not reject it. Second, character is the ability of an individual to be able to master these conditions ". By looking at the characters of the two sides of the character in a person is not a fixed price (static) but can change (dynamic). Human freedom allows character to develop into good and not vice versa. Characters are also closely related to "habit" or habits that are continuously practiced and practiced. Thus the character is not a result or a product but one of the results of one's efforts to overcome certain conditions. With the understanding that the character in a person is dynamic and very instrumental in determining the future of both themselves and their social environment, it is necessary for an educational effort that is able to develop one's character [18].

The importance of linking with the whole experience of education in civic education learning in the opinion of Kerr [19] on the need to develop Education for Citizenship which focuses on the process of "... equiping students with a set of tools (knowledge and understanding, skills and attitudes, values and dispositions) which enable them to participate actively and sensibly in the roles and responsibilities they encounter in their adult lives ". This approach links "citizenship education" to "the whole education experience of students". For that Winataputra and Budimansyah states "... The development of civic knowledge, skills, and attitudes is embedded in a complex system that includes parents, peers, civic organizations, and the media, but schools do have an important role to play ". Development of citizenship insights, skills and attitudes is integrated into a complex system, including parents, peers, civic organizations and the mass media, but schools do play an important role [20].

Civic Education takes on the mission of building the character of a citizen. But in addition, many experts, both implicitly and explicitly, state that Citizenship Education is character education such as the opinion of Somantri which states that Citizenship Education is held to train students/ students to think critically, analytically, think and act democratic in preparing a democratic life based on Pancasila and the 1945 Constitution [21]. Similarly, the opinion of Djahiri states that "Civics is a program of education / learning programatically-procedural attempt to humanize (humanizing) and civilizing (empowering) / student (self and life) to be a good citizen as the demands of the constitutional necessity / juridical nation / country concerned " [22]. In addition, Sapriya, also states that 'In the field of PIPS, the role of Civics has a large contribution both on the conceptual and operational level to build the character of citizens' [23]. Furthermore, Wahab and Sapriya concluded that the Civics have the primary mission of nurturing and developing citizens to have patriotism values and to build a commitment to democratic values based on a commitment to truth, honesty, independence, respect, freedom of expression [24]. Thus, Civics is very necessary and has a very strategic value and position for the nation's character building.

\section{CONCLUSION}

- Civic Education Practicum Material based on integrated learning is packed based on certain theme. An interesting theme was previously agreed to be a group study. The theme selection is determined by three classes on the subject of Customary Law, Constitutional Law and Islamic Law. The main study in this theme is related to the study of tolerance / peace. Tolerance / peace is seen from the perspective of Customary Law, Constitutional Law, and Islamic Law.

- Civics Practicum based on integrated learning is carried out by the DPRD Bandung City. Students who included 45 people consisting of group representatives. Each class has a group representation of 15 people so that if combined with other subjects then amounted to 45 people. The mentor is assigned as many as 3 people to guide each class representative in the subject of Customary Law, Constitutional Law and Islamic Law.

- Student perceptions related to the implementation of the model of practice based on integrated learning in the 
lecture include the suitability of the model with the learning component and the suitability of the model with the activity character's character's activity is considered good.

- Student perception related to character development after applying practice model based on integrated learning has been considered good especially the more prominent character that is gotong royong character.

- The impact of application of experimental model based on integrated learning on student character development has a significant effect of $52.3 \%$.

\section{REFERENCES}

[1] B. Ambarita, "Peningkatan Mutu, Relevansi Dan Daya Saing Perguruan Tinggi Menghadapi Era Globalisasi," GENERASI KAMPUS, vol. 3, no. $1,2010$.

[2] R. Megawangi, Pendidikan Karakter solusi yang Tepat untuk Membangun Bangsa, Bandung: BPMIGAS dan Energi, 2004.

[3] L. Cohen, L. Manion, and K. Morrison, Research Methods in Education (6thed.), London, New York: Routllege Falmer, 2007.

[4] Dictionary of Indonesian Language, 2001: 785

[5] M. Branson, Belajar Civic Education dari Amerika, Newyork Press, 1999.

[6] Sugiyono Metode Penelitian Pendidikan: Pendekatan Kuantitatif, Kualitatif, dan R\&D, Bandung: Alfabeta, 2009.

[7] W.R. Borg, and M.D. Gall, Educational Research: An Introduction (5thed), New York: Longman, 1989

[8] M.B. Miles and A.M. Huberman, "Drawing valid meaning from qualitative data: Toward a shared craft," Educational researcher, vol. 13, no. 5 , pp. 20-30, 1984.
[9] Sugiyono, Statistika untuk Penelitian, Bandung: Alfabeta, 2005.

[10] Depdikbud Republik Indonesia, Kurikulum Sekolah Umum Tingkat Atas (SMA): Petunjuk Pelaksanaan Proses Belajar Mengajar, 1990.

[11] A.H. Hernawan, Pengembangan Model Pembelajaran Tematik di Kelas Awal Sekolah Dasar, 2009.

[12] Sa'ud, Pembelajaran Terpadu, Bandung: UPI Press, 2006.

[13] Trianto, Model-model Pembelajaran Inovatif Berorientasi Konstruktivistik, Jakarta: Prestasi Pustaka, 2007.

[14] T. Sastrawijaya, Proses Belajar Mengajar. Jakarta :Depdikbud, Dirjendikti, Proyek Pengembangan Lembaga Pendidikan Tenaga Kependidikan, 1998.

[15] Ministry of Education and Culture, 2017

[16] T. Lickona, Educating Form Character How Our School Can Teach Respect and Responsibility, New York-Toronto-London-SidneyAuckland: Bantam Books, 1991.

[17] W.J. Bennet, Book of Virtue, New York: Simon \& Schuster Inc, 1991.

[18] D. Koesoema, Pendidikan Karakter, Strategi Mendidik Anak di Zaman Global, Jakarta: Grasindo, 2007.

[19] D. Kerr, Citizenship Education: an International Comparison, London, 1999.

[20] U. Winataputra, and D. Budimansyah, Civic Education Konteks, Landasan, Bahan Ajar dan Kultur Kelas, Bandung: Prodi PKN SPS UPI, 2007.

[21] M.N. Somantri, Menggagas Pembaharuan Pendidikan IPS, Bandung: PT. Remaja Rosda Karya, 2001.

[22] A.K. Djahiri, Budimansyah dan syaifullah (ed) Esensi Pendidikan NilaiMoral dan PKn dalam di Era Globalisasi, 70 tahun Prof. Kosasih Djahiri, Bandung: Lab PKn UPI, 2006.

[23] Sapriya, "Persepktif Pemikiran Pakar tentang Pendidikan Kewarganegaraan dalam Pembangunan Karakter Bangsa (Sebuah Kajian Konseptual-Filosofis PKn dalam Konteks Pendidikan IPS)," Acta Civicus: Jurnal Pendidikan Kewarganegaraan, vol. 1, no. 2, pp.199-214, 2008 .

[24] Wahab and Sapriya, Teori dan Landasan Pendidikan Kewarganegaraan, Bandung: CV Alfabeta, 2011. 